\title{
Nature of Mediation Clauses from the Point of View of Private International Law
}

\author{
Miluše Hrnčiříková \\ Faculty of Law, Palacký University Olomouc, Czech Republic \\ miluse.hrncirikova@upol.cz
}

HRNČIŘÍKOVÁ, Miluše Nature of Mediation Clauses from the Point of View of Private International Law. International and Comparative Law Review, 2019, vol. 19, no. 2, pp. 224-238 DOI: 10.2478/iclr-2019-0022.

Summary: Mediation as a popular method of ADR is more and more often used while solving cross border disputes. Although the mediation clauses are included into the commercial contracts almost automatically, no attention is paid to its validity, enforceability and other legal consequences. The article provides a study on the nature of mediation clauses that crucially influences the law governing validity of mediation clauses. It is the position of the author that mediation clauses are primary institutes of the substantive law and thus the governing law should be determined in accordance with the Rome I regulation.

Keywords: Mediation clause, substantive law, procedural law, governing law, foreign element, Rome I regulation

\section{Introduction $^{1}$}

The nature of ADR clauses, irrespective of the arbitration and choice of court clauses, is mainly influenced by the fact that it does not establish the jurisdiction of any decision making body. The task for the mediator is not to decide the case but to assist the parties to find an appropriate solution and to conclude an agreement. Mediation is a method of dispute settlement by which a third neutral qualified person helps the parties with communication whereas the main outcome is the satisfaction of the parties not only with the final agreement but also with the process itself. ${ }^{2}$ The result of mediation is not an enforceable final decision but a private agreement.

1 This article reflects results of the research GA ČR č. GA16-10589S Procesní doložky pro řešení přshraničních sporů - jejich platnost a vynutitelnost českými soudy that were published in Czech language in HRNČIŘÍKOVÁ, Miluše, HALLA, Slavomír, MALACKA, Michal, RYŠAVÝ, Lukáš. Mediační, prorogační a rozhodčí doložky o řešení preshraničních sporů. Prague: Leges, 2019, pp. 29-40.

2 HOLÁ, Lenka, Mediace v teorii a praxi. Prague: Grada, 2011, p. 52. 
In addition to the question of whether mediation clauses can be classified as institutes of procedural law or in substantive law, it is necessary first to consider the nature of mediation as such. ${ }^{3}$

\section{Mediation as an integral part of civil procedure? The Czech Civil Proce- dure Code perspective}

The legal definition of mediation is provided by $\$ 2$ a) of the Czech Mediation $\mathrm{Act}^{4}$ that states mediation is a procedure in setting a conflict with the participation of one or more mediators who support communication between the persons involved in the conflict in order to help them reach an amicable settlement of their conflict by concluding a mediation agreement. Further characteristics of mediation are mentioned in the Explanatory note to the Mediation Act. The mediator does not assert any concrete solutions, does not decide the dispute; mediation is based on the presumption that parties are able to solve their problem by themselves because they possess the ability to find the best solution, while the mediator helps them only to communicate and to find the path to an amicable and acceptable consensus. ${ }^{5}$ The Mediation Act permits several forms of mediation, facilitative as well as evaluative mediation. ${ }^{6}$ Mediation is not only an alternative to court proceedings or arbitration but it is a method of settlement of any (not only legal) conflicts in general.

On the other hand, civil judges have a duty to make an effort and encourage the parties to reach a settlement in the dispute, and thus mediation might be used in some cases. According to $\$ 114 \mathrm{a}$ (2) ( b) Civil Procedure Code the President of the Chamber notifies the parties of the possibility of using mediation under the Act on social mediation or counseling under the Act on Social Services, if appropriate. ${ }^{7}$ Where practical and appropriate, the presiding judge may order the parties to the first meeting with a registered mediator and stay the proceedings, but no longer than for three months. The informative meeting with the mediator should be 3 hours long. ${ }^{8}$ In both cases, however, mediation takes place outside court proceedings. The judge may stay the proceedings also according to $₫ 110 \mathrm{Czech}^{\mathrm{CPC}}{ }^{9}$ and to award the parties by chance to solve the

3 See MALACKA, Michal. Multi-Door Courthouse established through the European Mediation Directive?. International and Comparative Law Review, 2016, no. 1, pp. 127-142.

4 Act on Mediation and Change of Some Laws (Mediation Act) no. 202/2012 Coll.

5 Explanatory note to the Mediation Act, p. |43. .[online]. See https://www.psp.cz/sqw/text/ tiskt.sqw? $=6 \& C T=426 \& C T 1=0$ [ 10th September 2019].

6 GRYGAR, Jiří. Zákon o mediaci a související predpisy s komentářem a vzory. Podle stavu k1.1.2014. Prague: Leges, 2014, p. 13.

7 Act no. 99/1963 Coll. Civil Procedure Code (hereinafter CPC).

8 See $\$ 100(2)$ CPC.

$9 \$ 110$ CPC states: If that participants consistently suggest or if fails without prior excuse to act, or if at least one of the parties to propose and the other does not come without a prior excuse to act, the court shall stay the proceedings if it do not jam the proceedings. 
case outside court..$^{10}$ The judge may not order mediation, only when appropriate recommends mediation or he or she may force the parties to meet with a mediator to learn more about its potentials and advantages. In this situation to talk about mediation as a part of the civil procedure might be misleading and controversial.

Contrary to this conclusion, some authors suggest the possibility to conduct judicial mediation ${ }^{11}$ within the court proceedings according to $\$ 99$ (1) Czech CPC, which states:

If it accepts the nature of the case, the parties may terminate the proceedings judicial settlement. The Court seeks conciliation between the parties, in an attempt at conciliation. The President of the Chamber especially with the participants will discuss the matter, notify them of the rules and the opinions of the Supreme Court and the decision published in the Collection of judgments and opinions concerning the case and the circumstances of the case they recommend possibilities of an amicable solution dispute. If the nature of case is appropriate, notify the presiding judge the participants also of the possibility of using mediation under the Mediation Act or Act on Social Services.

It is our position that even if the term judicial mediation is used, it ought not to be accepted that the judge represents the function of the mediator in the sense of the Mediation Act. In this way of interpretation, it is only logical, that according to the last sentence of $\$ 99$ (1) CPC the judge may inform the parties about the possibility of mediation. It is true that a judge can use some techniques used in the mediation when encouraging the parties to reach an amicable settlement however it is not possible to assimilate the function of judge with the function of mediator. Furthermore, the judge's attempt to lead the parties to the settlement does not constitute an obstacle to his / her participation in the subsequent procedure or decision on the merits of the dispute. ${ }^{12}$ The possible breach of that duty of the judge does not give rise to a procedural irregularity which could lead to an incorrect decision. ${ }^{13}$

It is upon the discretion of the court which cases are appropriate for mediation and in what situation the parties might be sent to the meeting with a mediator. Participation in mediation cannot be enforced by execution and participants

10 KRÁLÍK, Michal, VAŠÍČEK, Jiří. \$114a (Konkrétní postup predsedy senátu při prŕpravě jednání) In: LAVICKÝ, Petr a kol. Občanský soudní ŕád: Praktický komentár. Prague: Wolters Kluwer ČR, 2016, p. 485.

11 HÁJKOVÁ, Šárka. $\$ 2$ In DOLEŽALOVÁ, Martina, HÁJKOVÁ, Šárka, POTOČKOVÁ, Dana, ŠTANDERA, Jan. Zákon o mediaci. Komentár. Prague: C.H.Beck, 2013.

12 Decision of the Regional Court in Brno - Branch Office in Zlín, 3rd November 2005, no. $60 \mathrm{Nc} 116 / 2005$.

13 HRÁDEK, Jiří. \$ 9. In LAVICKÝ, Petr a kol. Občanský soudní rád: Praktický komentár. Prague: Wolters Kluwer ČR, 2016, p. 38 et seq. 
cannot be forced to participate in it, for example under $\$ 52 \mathrm{CPC} .{ }^{14}$ It would be contrary to the fundamental characteristics of mediation that it can only be successful if there is a minimal will of all parties. Although a meeting with a mediator is sought only by one of the parties to a court, it is entirely within the court's discretion to use the procedure under $\$ 100$ (2) CPC and there is not a possibility to appeal against his or her decision not to refer the parties to the mediator. As the Municipal Court in Prague emphasizes, a negative decision based on the independent discretion of the judge does not affect the participants the right to a fair (judicial) trial, denied equal access to the court or the possibility of promptly hearing the dispute. The parties still have the right to attempt to start mediation while court proceedings are pending. On the contrary, the admissibility of an appeal would have led to the situation, whenever during the proceedings the party could have proposed the procedure under $₫ 100$ (2) CPC even if the proposal had been fully ungrounded. Thus the party would have been given a tool how to achieve undue delays in court proceedings. ${ }^{15}$

Some foreign legal systems may treat mediation differently and include it in their trials. ${ }^{16}$

\section{Mediation as an institute of private or public law}

The following analyses are dedicated mainly to the mediation of legal disputes and thus the next question coming into the mind of the reader might be whether regulation of mediation represents the public or private law branches of legal order.

Delineation of the public and private law is influenced by the tradition, historical legal backgrounds and legal theory. ${ }^{17}$ Approaches of several legal systems may be different. The main discrepancy is visible by comparing common and civil law. One of the famous glossators of the $13^{\text {th }}$ century Balduinus already distinguished between the rules ad decidendam litem and ad ordinandam litem, whereas the first ones apply to the merits of the case, the latter regulate the procedure of the judicial body. The doctrine is further elaborated by his followers, mainly Bartol de Sassoferrato, who stated " quoad ordinem litis inspicitur locus judicii", it means that the court proceedings are governed by the rules in force at the place where the judgment was rendered. ${ }^{18}$ Nowadays this principle rep-

14 Decision of the Regional Court in Hradec Králové, 17th February 2016, no. 21Co 62/2016.

15 Decision of the Prague Municipal Court, 17th April 2014, no. 23 Co 156/2014.

16 See HRNČǏ̌IIKOVÁ, Miluše, VALENTOVÁ, Lucie. Judiciální trendy v mimosoudním řšení přeshraničních sporů. Prague: Leges, 2016.

17 HURDÍK, Jan a kol. Občanské právo hmotné. Obecná část. Absolutní majetková práva. 2nd edition. Plzeň: Aleš Čeněk, 2014, pp. 35-39. ŠVESTKA, Jan, DVOŘÁK, Jan in DVOŘÁK, JAN, ŠVESTKA, JAN, ZUKLÍNOVÁ, MICHAELA a kol. Občanské právo hmotné. Díl první: obecná část. 2nd edition. Prague: Wolters Kluwer ČR, a. s. 2016, pp. 31-32.

18 PANAGOPOULOS, George. Substance and Procedure in Private International Law. Journal of Private International Law, 2005, no. 1, p. 69. 
resents one of the basics of private international law, even if it may lead to legal problems and controversies, since the application of the governing law is influenced by the qualification of the legal institute as of the procedural or substantive legal nature.

The law of civil procedure is part of public law from the point of view of the Czech legal order, contrary to the regulation of mediation. Mediation cannot be classified as an institute of public law either in terms of power, interest or organic theory. The method of legal regulation is then determined by the technique and degree of exercise of public power by the legislature through legal norms: While public law uses public power by directly affecting the legal situation of participants through public authorities, the legislative method of private law consists in leaving a relatively wide scope to party autonomy. ${ }^{19}$ However, even when examining the Mediation Act, it is not possible to deduce that it can be classified as a norm of public law.

One of the aims of civil procedure is to secure the protection of civil law relationships and subjective rights by the public authority. The range of the powers of public authorities is determined by constitutional acts. Art. 2 (2) of the Charter of Fundamental Rights and Freedoms states:

State authority may be asserted only in cases and within the bounds provided for by law and only in the manner prescribed by law. ${ }^{20}$

The mediator is not a public authority with any public power and he or she does not provide the parties with any guarantee of protection of their subjective rights. Mediation is based on the principle of self-determination and the mediator, as the third neutral subject, is merely the intermediary of communication between the parties.

If any breach of the duties and rights in the process of mediation occurs, only civil law remedies exist. Similarly, Hájková mentions that the mediation clause is not an obstacle to civil proceedings but represents an obligation and therefore it is possible that the other party will claim damages caused by such conduct. ${ }^{21}$

Based on these arguments the conclusion should be made, that mediation is an institute of private law and the Mediation Act is part of private law and on the contrary it is not regulated by civil procedure law, that is part of the public law.

On the other side, the mediation clause also contains regulation of a procedure. This fact is pointed out by Zoulík, who expresses some hesitation that the mediation clause can be included under the regulation of innominate contract, in

19 HURDÍK, Jan in HURDÍK, Jan a kol. Občanské právo hmotné. Obecná část. Absolutní majetková práva. 2nd edition. Plzeň: Aleš Čeněk, 2014, p. 38.

20 Constitutional act no. 2/1993 Coll.

21 HÁJKOVÁ, Šárka. $\$ 3$ In DOLEŽALOVÁ, Martina, HÁJKOVÁ, Šárka, POTOČKOVÁ, Dana, ŠTANDERA, Jan. Zákon o mediaci. Komentár. Prague: C.H.Beck, 2013, p. 15 et seq. 
the sense of the previously valid $\$ 51$ Czech Civil Code. This approach is deduced from the content of the mediation clause itself which the aforementioned provision invokes and deals with procedural (in the meaning of organization) issues. For this reason, Zoulík further recommends that it would be desirable to invent a special regulation on the mediation clause, comparable to the arbitration clauses regulation. ${ }^{22}$

The substantive law nature of the mediation clauses is also recognized by Bělohlávek. ${ }^{23}$ Bělohlávek recognizes two types of consequences of non-compliance with the mediation clause. On the one hand, the legal action may be dismissed because the failure to comply with the negotiated procedure may cause the action to be premature. However, if the disputes between the parties are already so escalated that mediation is no longer possible, failure to comply with the negotiated procedure may become a mere obstacle to the exercise of substantive law in the judicial proceedings. Therefore, depending on the circumstances, the mediation clause may either cease to exist or become obsolete or do not evolve any legal effect. ${ }^{24}$

The mediation clause has a strictly private law nature according to Coufalík, who proposes that in the case of ADR procedure the term "private procedure law" might be used and invokes the legal definition of party autonomy guaranteed by art. 2 (4) of the Constitution ${ }^{25}$ and art. 2 (3) of the Charter of Human Fundamental Rights and Freedoms ${ }^{26}$. Moreover, he explains that it is not acceptable to compare the mediation clause with arbitration or prorogation clauses which are recognized as procedural agreements with a mixed nature. Due to its similarity to this type of clauses, mediation clauses can be described as a "quasiprocedural agreement".

On the contrary, Pauknerová and Pfeiffer recognize that the mediation clause may have a rather mixed nature. Even though, they do not examine the nature of the mediation clause as such, according to their conclusions concerning mediability (similar to arbitratibity in the case of arbitration) that should have been governed by the law of the place of mediation or where the potential mediation agreement is enforced, the mixed nature of the mediation clause can be deduced,

22 ZOULÍK, František. Mediace jako alternativa soudního sporu. Bulletin advokacie, 2001, no. 8 , p. 29.

23 BĚLOHLÂVEK, Alexander, J. Římská úmluva/Nařízení Řím I. Komentáŕ. Prague: C.H.Beck, 2009, p. 318.

24 BĚLOHLÁVEK, Alexander, J. Římská úmluva/Nařizení Řím I. Komentár̆. Prague: C.H.Beck, 2009, p. 319.

25 Art. 2 (4) Constitutional Act no 1 / 1993 Coll., Constitution of the Czech Republic states: 4) All citizens may do that which is not prohibited by law; and nobody may be compelled to do that which is not imposed upon them by law.

26 Art 2 (3) Constitutional Act no. 2/1993 Coll., Charter of Fundamenta Humanl Rights and Freedoms states : (3) Everyone may do that which is not prohibited by law; and nobody may be compelled to do that which is not imposed upon her by law. 
if some part of this clause is governed by the law determined by the conflict of laws rules and other parts by the procedural law of the place of mediation. ${ }^{27}$

It can be sumed up that from the perspective of the Czech law and theory conclusion of the mediation clause is not reflected by the court proceedings and the consequences of the conclusion of the mediation clause is merely in the field of substantive law. ${ }^{28}$ Mediation is based on the consensus that is necessary throughout the whole process of mediation, the parties cannot be forced to participate in mediation. Nor does the Czech Civil Procedure Code recognize any legal effect of the mediation clause at the beginning of the proceedings and thus its reflection without any legal grounds might lead to the breach of the art. 6 of the European Charter of Human Rights. Although, the mediation clause does not establish the jurisdiction of any subject to decide the dispute, it deals with procedural issues that concern legal disputes, but primarily in a non-legal way. It might be compared to assisted negotiations, when we can distinguish between negotiating a new contract and negotiating a dispute settlement. After the dispute has arisen, the parties may agree to attempt to settle the dispute between them, or they can send a request for the protection of their rights to the authority having the public power to decide the dispute. ${ }^{29}$

This qualification of the mediation clause should have been reflected also in the case of mediation clauses with a foreign element and the applicable law determined mainly by the conflict of laws rules.

\section{Rome I Regulation and mediation clauses}

In the case of mediation clauses with a foreign element it is decisive whether provisions of Rome I Regulation ${ }^{30}$ apply. Art. 1 (2) e) of the Rome I Regulation states that arbitration agreements and agreements on the choice of court shall be excluded from the scope of this Regulation and art. 1 (3) Rome I Regulation states that this Regulation shall not apply to evidence and procedure, without prejudice to Article 18. This raises the question whether, on the basis of these provisions, the mediation clause is excluded from the scope of the Regulation or not. Even if we accept the substantive nature of the mediation clause, doubts may still arise about the application of the Rome I Regulation. Indeed, some authors point out that a mediation clause is excluded from the scope of the Regulation solely by analogy to an arbitration or prorogation clause, which does not auto-

27 PAUKNEROVÁ, Monika, PFEIFFER, Magdalena. Mezinárodní mediace a české právo. Právní rozhledy, no. 1, 2013, pp. 22-24.

28 From the point of view of Czech law, the impact on the limitation periods is also seen as a substantive law issue.

29 DVOŘÁK, Jan, ŠVESTKA, Jan, ZUKLÍNOVÁ, Michaela et al. Občanské právo hmotné. Díl první: obecná část. 2nd edition. Prague: Wolters Kluwer ČR, a. s., p. 39.

30 Regulation (EC) no 593/2008 of the European Parliament and of the Council of 17 June 2008 on the law applicable to contractual obligations (Rome I). 
matically exclude its substantive nature. Moreover, it should be remembered that although the Rome I Regulation would not apply to the determination of the applicable law for the mediation clause (because of its exclusion), the application of the conflict-of-law provisions of national law is still possible, ${ }^{31}$ since the position of the EU law to the nature of mediation clause is not determined.

The nuclear position of EU to dispute resolution clauses is evidenced from the explicit exclusion of the arbitration and prorogation clauses in art. 1 (2) (e) of the Rome I Regulation. If there was a consensus on their procedural nature, the inapplicability of the Regulation would already have been derived from the provisions of art. 1 (3) of the Regulation. The provision excluding the arbitration agreement and the choice of court agreement from the scope of the Rome I Regulation has been taken over from the Rome Convention of $1980^{32}$, from art. 1 (2) (h). The reason was the same as in the Regulation - inconsistent approach of the shareholder to the nature of these clauses. ${ }^{33}$ In particular, the UK delegation opposed the exclusion, as English law traditionally asserts the substantive nature of arbitration clauses. ${ }^{34}$ On the other hand, the French and German delegations opposed this approach, stating that extending legal regulation in this area would not be productive. There are already some universally acceptable principles of arbitration clauses, e.g. the separability of the arbitration clause, on the contrary, it is not feasible to distinguish the substantive and the procedural aspects of the arbitration clause, there is no consensus on the legislation, including arbitrability, and in the end only the issue of consensus would have been regulated. ${ }^{35}$

A similar attitude was taken during the phase of preparation for the transformation of the Rome Convention into a Regulation, however, not many delegations did address this exemption. The Latvian delegation merely drew attention to the conflict rules vested in the Hague Convention on Choice of Court Agreements and the appropriateness of including a similar rule into the Regulation. In the course of the following discussion, this proposal did not involve any greater interest and, finally, Article 1 (2) (a) (e) of the Rome I Regulation was adopted as proposed. ${ }^{36}$

31 See HARSÁGI, Viktória, CZOBOLY, Gergely, NEMESSÁNYI, Zoltán. Hungary in ESPLUGUES, Carlost (edt). Civil and Commercial Mediation in Europe. Volume II. Cambridge: Intersentia Publishing, 2014, p. 204.

32 80/934/EEC: Convention on the law applicable to contractual obligations opened for signature in Rome on 19 June 1980.

33 MCPARLAND, Michael. The Rome I Regulation on the Law Applicable to Contractual Obligations. London: Oxford, 2015, p. 231 et seq. .

34 GIULIANO, Mario, LAGARDE, Paul. Report on the Convention on the law applicable to contractual obligations, p. 12.[online]. See https://eur-lex.europa.eu/LexUriServ/LexUriServ.do?uri=CELEX:31980Y1031(01):EN:HTML [ 5th November 2018].

35 GIULIANO, Mario, LAGARDE, Paul. Report on the Convention on the law applicable to contractual obligations, s. 12.[online]. See https://eur-lex.europa.eu/LexUriServ/LexUriServ.do?uri=CELEX:31980Y1031(01):EN:HTML [5th November 2018].

36 MCPARLAND, Michael. The Rome I Regulation on the Law Applicable to Contractual Obligations. London: Oxford, 2015, p. 235. 
Even if the distinction between procedural agreements (arbitration and choice of court clauses) and mediation clause is recognized, to exclude the application of Rome I Regulation is still possible according to art. 1 (3) of the Rome I Regulation. This article is a reflection to art. 1 (2) (h) of the Rome treaty. The necessity of the definition of the procedure in the sense of art. 1 (3) of the Rome Regulation is clear. Some indicia might be detected from scope of the law applicable (lex causae) vested into the art. 12 of the Rome I Regulation and inclusion of art. 18 of the Rome I Regulation within its content. That means, inter alia, that the law applicable to a contract by virtue of the Rome I Regulation shall govern in particular the various ways of extinguishing obligations, and prescription and limitation of actions ${ }^{37}$ even if this legal institute may by considered as procedural according to national law. ${ }^{38}$

Moreover the definition of the substantive issues must be provided in the context of art. 15 and art. 22 of the Rome II on the law applicable to non-contractual obligations, since the procedural exclusion contained in art. 1 (3) of the Rome II regulation is similar to the previously mentioned Rome I Regulation.

Out of this legal framework of the Regulation, general question may be posed - is there any binding characterization of the court proceeding provided by the EU law, might the autonomous interpretation be used or is the interpretation of this term reserved for the national legal order and legal theory? On the basis of legislative and historical backgrounds, McParland concludes that the EU legislation does not intend, nor can it be brought to attempt to establish an autonomous and universal definition of the court proceeding and to draw the sharp line between procedural and substantive law. It is within the competences of the national court by the application of the lex fori to determine the nature of the relevant legal institute ${ }^{39}$ Contrary to this statement, Illmer recommends to create an autonomous definition to deline the procedural and substantive law that would be based on neutrality. ${ }^{40}$

Regardless of whether the definition of procedural law is accepted by the EU Court of Justice or not, it is generally recommend that it might be based on a narrower concept of procedural law consisting primarily in defining the civil process as such. ${ }^{41}$ Especially English law provides a broad definition of the procedural law, considering as substantive law institutes that represents certain

37 See art. 12 (1) (d) of the Rome I Regulation

38 MCPARLAND, Michael. The Rome I Regulation on the Law Applicable to Contractual Obligations. London: Oxford, 2015, p. 267.

39 MCPARLAND, Michael. The Rome I Regulation on the Law Applicable to Contractual Obligations. London: Oxford, 2015, p. 269.

40 ILLMER, Martin. Neutrality Matters - Some Thoughts about The Rome Regulation and the So-Called Dichotomy of Substance and Procedure in European Private International Law. Civil Justice Quarterly, 2009, no. 28, p. 237 et seq.

41 GARNETT, Richard. Substance and procedure in Private international law. Oxford: Oxford University Press, 2012, p. 39. 
rights and obligations and procedural law institutes that ensure the enforcement and remedies arising out of violations of substantive law - the so-called right / remedy view. ${ }^{42}$ This approach allows the judge to eliminate the application of the conflict of law rules and consequently the foreign law more frequently and lead to a predominant application of lex fori.

The acceptance of the rule that forum law governs procedure and the delineation between procedural and substantive law only appeared in the early 18th century in the English law, when the application of foreign law was increasingly argued. ${ }^{43}$ The border line between the perception of substantive and procedural law is shifted in the context of common law and when compared with the continental legal tradition, since the rules related to the enforcement of substantive claims are also considered to be procedural law. The lex fori regit processum rule is thus more easily misused, either it may ensure ease of the proceedings or eliminate the need to ascertain the content of the foreign law. Judge Arden accurately mentioned: „In my judgment, when in the conflict of laws, the court says that a particular issue is one of procedure rather than substance, the court is really saying that it cannot, for whatever reason, apply the relevant foreign law to that issue." ${ }^{44}$

These discrepancies of the different legal attitudes of the legal systems may influence not only the right to a fair trial but also forum shopping. Especially when we realize that a given legal institute is usually qualified first according to the lex fori, which, if the court concludes that it is an institute of substantive law may lead to the application of foreign law, and the judge may face the dilemma which law should he or she apply if the governing law qualifies the institute as an institute of procedural law. In recent years, however, there has been a trend of deviation from the very broad concept of procedural law in areas of common law, for example, Australian courts invoke the application of the forum procedural law only when it relates to court proceedings. ${ }^{45}$

The application of the provisions of the Rome I Regulation to mediation clauses is thus not accepted universally in all EU jurisdictions, since the autonomous interpretation of art. 1 (3) of the Rome I Regulations opens the space for diversity.

42 GARNETT, Richard. Substance and procedure in Private international law. Oxford: Oxford University Press, 2012, p. 10 et seq.

43 GARNETT, Richard. Substance and procedure in Private international law. Oxford: Oxford University Press, 2012, p. 7.

44 PANAGOPOULOS, George. Substance and Procedure in Private International Law, Journal of Private International Law, no. 1, 2005, p. 69 et seq. See CARRUTHERS, Janeen M. Damages in the Conflict of Laws - The Substance and Procedure Spectrum: Harding v. Wealands. Journal of Private International Law, no. 1, 2005, p. 323 et seq.

45 Decision High Court of Australia,19th December 1991,MCKain vs. RW Miller \&Co (South Australia) Pty Ltd., (1992) 174 CLR 1. Decision High Court of Australia, 21st June 2000, John Pfeiffer Pty Limited v Rogerson, [2000] HCA 36. 


\section{Law governing mediation clauses according to Rome I Regulation}

Even if the presumption that the mediation clause is not excluded from the scope by virtue of the relevant provisions of art. 1 of the Rome I Regulation, it is necessary to ask another question - which conflict of laws provision is applicable to determine the law applicable. However, as a number of published opinions show, there is no clear conclusion. This can only be dome in a situation where the parties in the mediation agreement have explicitly agreed on the law applicable to their mediation clause, since under the provisions of Article 3 of the Rome I Regulation, the contract is governed by the law chosen by the parties.

Where the choice of law has not been made by the parties, it is possible to determine the applicable law under the provisions of art. 4 (4) of the Rome I Regulation, i.e. the contract shall be governed by the law of the country with which it is most closely connected, or art. 4 (1) (b) Rome I Regulation, by the law of the country where the service provider has his habitual residence.

As the prevailing approach is considered the application of the law determined via art. 4 (4) Rome I Regulation, the mediation clause is governed by the law of the country with which the clause is most closely connected. However, this provision is applicable only where art. 4 (1) of the Rome I Regulation, which contains an exhaustive list of certain types of contracts, or Article 4 (2) of the Rome I Regulation, are not applicable. The parties to the mediation clause are the parties to the main contract which undertake the obligation to resolve their possible disputes through mediation. The mediation clause thus can be described as an innominate contract that cannot be included under any of the contracts listed in Article 4 (1) of the Rome I Regulation.

On the other hand, according to some authors it is necessary to consider the provisions of art 4 (1) (b) of the Rome I Regulation concerning the determination of the law applicable to service contracts and to determine the law of the country where the service provider has their habitual residence. ${ }^{46}$ However, it must be bared in mind, that the mediator is not a party to the mediation clause and the parties to the mediation clause only undertake to act in a certain way when resolving the conflicts arising out of the main contract. Moreover, according to some authors, it is also questionable whether the mediator can be regarded as a service provider within the meaning of that provision. Nevertheless, there are still the opinions that the law applicable to the mediation clause should be determined according to the mediator's habitual residence. ${ }^{47}$

46 KNEZ, Rajko, WEINGERL, Petra. Slovenia in ESPLUGUES, Carlost (edt). Civil and Commercial Mediation in Europe. Volume II. Cambridge: Intersentia Publishing, 2014, p. 404.

47 EMILIANIDES, Achilles C., CHARALAMPIDOU, Natalia. Cyprus ESPLUGUES, Carlost (edt). Civil and Commercial Mediation in Europe. Volume II. Cambridge: Intersentia Publishing, 2014, p. 112. 
According to art. 4 (2) of the Rome I Regulation where the contract is not covered by paragraph 1 , the contract shall be governed by the law of the country where the party required to effect the characteristic performance of the contract has their habitual residence. However in the case of mediation clauses it is hardly possible to determine the party providing the characteristic performance. Thus, the procedure laid down in art. 4 (4) of the Rome I Regulation remains, and it is therefore necessary to determine which country the mediation clause is most closely connected to. The determination of the country with the closest connection should be provided in accordance with paragraph 21 of the Preamble of the Rome I Regulation saying that in order to determine that country, account should be taken, inter alia, of whether the contract in question has a very close relationship with another contract or contracts. ${ }^{48}$

Other indicia leading to the determination of the state with the closest connection are provided by the case law and literature. This state should be determined according to the objective criteria and regardless of the law applicable in that state. ${ }^{49}$ The law applicable to the mediation clause is most likely to be the law of the country where the mediation takes place, resp. should take place. Thus, the country may be the country where the seat of the organization where the mediation is to be conducted, is located, although the mediation may in fact take place in another country. In certain cases, the law of the country in which both parties have their habitual residence may be considered as applicable. The law applicable to the main contract may also affect the determination of the law applicable to the mediation clause, since the theory of separabilty is generally accepted also in the case of mediation clauses. If there are a large number of countries connected to the mediation clause, the place where the mediation clause has been concluded may be decisive,$^{50}$ although with a massive boom in electronic communications, this factor is nowadays increasingly lagging behind. ${ }^{51}$

It is a common practice that mediation clauses represent first of the levels of the multi-level (multi-tier) dispute resolution clauses and thus the state where the potential subsequent judicial or arbitration proceedings are to take place should also be taken into account. Maybe a parallel could be made as to the impact of the prorogation clauses to the implicit choice of law in the sense of paragraph 12 of the Preamble of the Rome I Regulation, that states that an agree-

48 Par. 21 Preamble Rome I Regulation.

49 MCPARLAND, Michael. The Rome I Regulation on the Law Applicable to Contractual Obligations. London: Oxford, 2015, p. 439.

50 Decision England and Wales High Court (Chancery Division) Decisions, 7th April 2004, Apple Corps Ltd v Apple Computer Inc, EWHC 7682 CLC 720. MCPARLAND, Michael. The Rome I Regulation on the Law Applicable to Contractual Obligations. London: Oxford, 2015, p. 440.

51 MCPARLAND, Michael. The Rome I Regulation on the Law Applicable to Contractual Obligations. London: Oxford, 2015, p. 436. KYSELOVSKÁ, Tereza. Vybrané otázky vlivu elektronizace na evropské mezinárodní právo soukromé a procesní. Brno: Masarykova univerzita, 2014. 
ment between the parties to confer on one or more courts or tribunals of a Member State exclusive jurisdiction to determine disputes under the contract should be one of the factors to be taken into account in determining whether a choice of law has been clearly demonstrated. Moreover, the CJEU acknowledged that in the case of determining the law applicable on the basis of the closest connection, the court has taken into account all the circumstances, including the existence of other contracts related to the contract. ${ }^{52}$

The scope of the application of the governing law is defined by art. 12 of the Rome I Regulation. Lex cause shall govern in particular the interpretation, performance, within the limits of the powers conferred on the court by its procedural law, the consequences of a total or partial breach of obligations, including the assessment of damages in so far as it is governed by rules of law, the various ways of extinguishing obligations, and prescription and limitation of actions, the consequences of the nullity of the contract. ${ }^{53}$ The formal validity of the mediation clause is governed by the law determined by the conflict of laws rules included in art. 11 of the Rome I regulation and material consent with the mediation clause is governed by the law determined by art. 10 of the Rome I regulation.

One of the separate questions is which cases may be resolved in mediation. Some authors use the above term already mentioned - mediability, i.e. the ability of a dispute to be the subject of mediation. ${ }^{54}$ In this case, some of the authors compare it with an equivalent for arbitrations (arbitrability) of the case) and propose the application of the lex fori. Similarly, at the stage of eventual enforcement of a mediation agreement, it would be necessary to examine mediability according to the law of the state where the agreement is to recognize and enforced..$^{55}$ Similar approach has been vested into the art. 5 (2) (b) of the Singapore convention on mediation. ${ }^{56}$

Questions involving the status or the legal capacity of natural persons as well as questions governed by the law of companies and other bodies, including its legal capacity, are excluded (without prejudice to art. 13) from the Rome I Regulation. The governing law is thus determined according to other conflict of laws rules, in most cases included into the national private international law acts. In

52 Judgment ECJ 23rd October 2014, no. C 305/13, Haeger \& Schmidt GmbH v. Mutuelles du Mans assurances IARD (MMA IARD).

53 See art. 12 (1) Rome I Regulation.

54 PAUKNEROVÁ, Monika, PFEIFFER, Magdalena. Mezinárodní mediace a české právo. Právní rozhledy, no. 1, 2013, p. 22 et seq.

55 PAUKNEROVÁ, Monika, PFEIFFER, Magdalena. Mezinárodní mediace a české právo. Právní rozhledy, no. 1, 2013, p. 23.

56 United Nations Convention on International Settlement Agreements Resulting from Mediation ((the Singapore Convention on Mediation) states: The competent authority of the Party to the Convention where relief is sought under article 4 may also refuse to grant relief if it finds that: the subject matter of the dispute is not capable of settlement by mediation under the law of that Party. 
terms of the Czech law the provisions are vested mainly in $₫ 29$ and $\$ 30$ of the Czech Private International Law Act.

\section{Conclusion}

The conclusions regarding the mediation clause presented in this article represent only one of the possible approaches, which is mainly influenced by the Czech legal environment and the doctrine of private international law. As in the case of arbitration, there is almost a certainty that the legal perspectives on mediation and mediation clauses will evolve, change and refine in the future. We may expect that the Singapore Convention on mediation and its application by national courts will contribute to this evolution. As a conclusion it might be stated that the access to mediation clauses as to the institutes of substantive law to which the conflicting provisions of Rome I Regulation are applicable reflects one of the possible solutions and only further developments will show whether it will be accepted and confirmed.

\section{References}

BĚLOHLÁVEK, Alexander, J. Římská úmluva/Nařízení Řím I. Komentář. Prague: C.H.Beck, 2009.

CARRUTHERS, Janeen M. Damages in the Conflict of Laws - The Substance and Procedure Spectrum: Harding v. Wealands. Journal of Private International Law, no. 1, 2005.

EMILIANIDES, Achilles C., CHARALAMPIDOU, Natalia. Cyprus ESPLUGUES, Carlost (edt). Civil and Commercial Mediation in Europe. Volume II. Cambridge: Intersentia Publishing, 2014.

Explanatory note to the Mediation Act, p. |43. .[online]. See https://www.psp.cz/sqw/text/ tiskt.sqw? $\mathrm{O}=6 \& \mathrm{CT}=426 \& \mathrm{CT} 1=0$ [ 10th September 2019].

GARNETT, Richard. Substance and procedure in Private international law. Oxford: Oxford University Press, 2012.

GIULIANO, Mario, LAGARDE, Paul. Report on the Convention on the law applicable to contractual obligations, p. 12.[online]. See https://eur-lex.europa.eu/LexUriServ/LexUriServ.do?uri=CELEX:31980Y1031(01):EN:HTML [ 5th November 2018].

GRYGAR, Jiří. Zákon o mediaci a související prededisy s komentářem a vzory. Podle stavu $k$ 1.1.2014. Prague: Leges, 2014.

HÁJKOVÁ, Šárka. $\$ 2$ In DOLEŽALOVÁ, Martina, HÁJKOVÁ, Šárka, POTOČKOVÁ, Dana, ŠTANDERA, Jan. Zákon o mediaci. Komentář. Prague: C.H.Beck, 2013.

HARSÁGI, Viktória, CZOBOLY, Gergely, NEMESSÁNYI, Zoltán. Hungary in ESPLUGUES, Carlost (edt). Civil and Commercial Mediation in Europe. Volume II. Cambridge: Intersentia Publishing, 2014.

HOLÁ, Lenka, Mediace v teorii a praxi. Prague: Grada, 2011.

HRÁDEK, Jiří. $\$$ 9. In LAVICKÝ, Petr a kol. Občanský soudní rád: Praktický komentář. Praha: Wolters Kluwer ČR, 2016.

HRNČǏ̌IKKOVÁ, Miluše, HALLA, Slavomír, MALACKA, Michal, RYŠAVÝ, Lukáš. Mediační, prorogační a rozhodčí doložky o řešení preshraničních sporů. Prague: Leges, 2019. 
ICLR, 2019, Vol. 19, No. 2.

HRNČǏ̌IIKOVÁ, Miluše, VALENTOVÁ, Lucie. Judiciální trendy v mimosoudním řešení preshraničnich sporů. Prague: Leges, 2016.

HURDÍK, Jan a kol. Občanské právo hmotné. Obecná část. Absolutní majetková práva. 2nd edition. Plzeň: Aleš Čeněk, 2014.

ILLMER, Martin. Neutrality Matters - Some Thoughts aboutThe Rome Regulation and the So-Called Dichotomy of Substance and Procedure in European Private International Law. Civil Justice Quarterly, 2009, no. 28.

KNEZ, Rajko, WEINGERL, Petra. Slovenia in ESPLUGUES, Carlost (edt). Civil and Commercial Mediation in Europe. Volume II. Cambridge: Intersentia Publishing, 2014.

KRÁLÍK, Michal, VAŠÍČEK, Jiří. S $114 a$ (Konkrétní postup predsedy senátu při př́pravě jednání) In: LAVICKÝ, Petr a kol. Občanský soudní rád: Praktický komentár. Prague: Wolters Kluwer ČR, 2016.

KYSELOVSKÁ, Tereza. Vybrané otázky vlivu elektronizace na evropské mezinárodní právo soukromé a procesní. Brno: Masarykova univerzita, 2014.

MALACKA, Michal. Multi-Door Courthouse established through the European Mediation Directive? International and Comparative Law Review, 2016, no. 1.

MCPARLAND, Michael. The Rome I Regulation on the Law Applicable to Contractual Obligations. London: Oxford, 2015.

PANAGOPOULOS, George. Substance and Procedure in Private International Law, 1 Journal of Private International Law, no. 1, 2005.

PAUKNEROVÁ, Monika, PFEIFFER, Magdalena. Mezinárodní mediace a české právo. Právní rozhledy, no. 1, 2013.

ŠVESTKA, Jan, DVOŘÁK, Jan in DVOŘÁK, Jan, ŠVESTKA, Jan, ZUKLÍNOVÁ, Michaela et al. Občanské právo hmotné. Díl první: obecná část. 2nd edition. Prague: Wolters Kluwer ČR, a. s. 2016.

ZOULÍK, František. Mediace jako alternativa soudního sporu. Bulletin advokacie, no. 8, 2001. 